\title{
Shaming of Tax Evaders: Empirical Evidence on Perceptions of Retributive Justice and Tax Compliance Intentions
}

\author{
Oliver Nnamdi Okafor ${ }^{1}$
}

Received: 3 March 2021 / Accepted: 27 November 2021 / Published online: 3 January 2022

(c) The Author(s) 2021

\begin{abstract}
Although naming-and-shaming (shaming) is a commonly used tax enforcement mechanism, little is known about the efficacy of shaming tax evaders. Through two experiments, this study examines the effects of shaming tax evaders on third-party observers' perceptions of retributive justice and tax compliance intentions, and whether the salience of persuasion of observers moderates these relationships. Based on insights from defiance theory, the message learning model, and persuasive communications, this study predicts and finds that shaming evaders increases observers' tax compliance intentions. Furthermore, the results show that higher persuasion, which includes sanction and normative appeals, affects observers' tax compliance intentions. This study also suggests that shaming has a positive effect on perceptions of retributive justice. Importantly, the results reveal that perceptions of retributive justice in shaming punishment mediate the effect of shaming on tax compliance intentions. The implications for theory and practice are discussed.
\end{abstract}

Keywords Naming-and-shaming $\cdot$ Persuasion $\cdot$ Hierarchical regression $\cdot$ Retributive justice $\cdot$ Tax evasion $\cdot$ Tax compliance

\section{Introduction}

Tax authorities deploy a variety of measures such as audits, prosecutions, naming-and-shaming (shaming) and persuasive communications to enforce compliance (Alm \& Torgler, 2011; Devos \& Zackrisson, 2015; Hasseldine et al., 2007; Luttmer \& Singhal, 2014). Shaming which includes publicizing tax offenders, their offenses and punishments to deter tax evasion and raise tax revenue, has received limited attention in the tax literature. Many tax authorities in the Organization for Economic Co-operation and Development (OECD) and other countries have used shaming to enforce compliance (OECD, 2019). For example, the tax authority in Ireland publishes a list of tax offenders, including their addresses, quarterly in the country's official newspaper of record, Iris Oifigiuil (Revenue Commissioners, 2020). Some US states use or have used shaming to enforce tax compliance (Luttmer \& Singhal, 2014; Perez-Truglia \& Troiano, 2018) and the Canada Revenue Agency (CRA) publicizes convictions for tax offenses (tax conviction notices)

Oliver Nnamdi Okafor

oliver.okafor@ ryerson.ca

1 Ted Rogers School of Management, Ryerson University, Toronto, ON, Canada involving fraud and failure to file tax returns (Canada Revenue Agency, 2020). The CRA uses tax conviction notices to shame tax evaders by publicizing their names, crimes and punishments to demonstrate that justice has been served for a tax evader's action. The Canadian tax authority also uses conviction notices to warn would-be tax offenders that it takes its job seriously and will detect and punish offensive tax behavior. Because punishments may prevent offenders from doing more harm and prevent others from committing similar crimes (Beccaria, 2009), future tax compliance may improve without a tax authority spending more resources on enforcement when the tax authority publicizes how it enforces compliance. However, it is plausible that when individuals are presented with an egregious case of tax evasion, they morally rationalize their own cheating behavior and engage in more cheating. Shaming can deter, be defied or have no effect on future crimes (Sherman, 1993). Therefore, it is important to investigate the conditions under which public disclosure of offenses and punishments of tax evaders may increase the perceptions of retributive justice and tax compliance intentions.

Despite shaming being a fervent topic in tax compliance, the effects of shaming and the content of its message on retributive justice perceptions and tax evasion are unexplored. To help address this gap, this study asks the 
following question: How do publicizing tax evader punishments and the content of messages affect third-party observers' perceptions of retributive justice and tax compliance intentions? Perceived retributive justice refers to observers' perceptions of the appropriateness of punishments applied to convicted and shamed tax evaders. Tax evasion is the deliberate omission of income from tax returns, overstatement of tax deductions or failure to file required tax returns for the purpose of paying less or no taxes. Canada is the setting chosen for this study due to its wide use of tax conviction notices as an instrument for shaming tax evaders.

When applying existing research on shaming to tax compliance, there is scant literature for reference, and study outcomes are mixed. For example, "increasing the salience of shaming penalties has a positive effect on the payment rate" for delinquent debts below $\$ 2500$, but providing information on the delinquencies of tax debtors' neighbors does not affect payment rates (Perez-Truglia \& Troiano, 2018, p. 133). Moreover, because shamed tax directors and corporations do not seem to suffer any significant backlash, shaming may not reduce tax abuse (Blank, 2009). Shaming a corporation may even backfire by sending a positive signal to investors or potential investors that the company makes efforts to reduce its tax expenses to maximize shareholder values (Blank, 2009). According to Bramall (2018), shaming may not be a good deterrent against tax injustice for celebrities because it could lead to an increase in noncompliance for taxpayers who identify with the shamed celebrity. Although the IRS publicizes high-profile individuals prosecuted for tax fraud as a supplementary method to enforce compliance (Branham, 2008), the impact of this publicization has not been empirically examined. Garz and Pagels (2018) use archival data to examine celebrity tax compliance and find that increased media coverage of tax evader trials in Germany increased participation in tax amnesty programs. These few studies, which essentially exhaust the research on shaming and tax compliance, do not empirically investigate the effects of tax evaders' shaming punishments on observers' perceptions of retributive justice and their tax compliance intentions. These studies do not use randomized experiments, unlike the current study.

The current study uses insights from Sherman's (1993) defiance theory, the Yale Model of Persuasion and Hasseldine et al.'s (2007) persuasive communications to investigate the effects of shaming punishments and the contents of shaming messages on observers' perceived retributive justice and tax compliance intentions. It uses publicization of tax convictions as a mechanism through which shaming and the contents of shaming messages could affect tax evasion. Because retributive justice relates to tax compliance (Kirchler et al., 2008; Okimoto \& Wenzel, 2009; Rechberger et al., 2010), the current study further investigates whether observers' perceptions of retributive justice in shaming punishment mediate the relationships between shaming and tax compliance.

This study relates to and builds on the shaming, retributive justice and behavioral tax compliance literature. First, this study responds to the call for more studies that assess how shaming may affect aspects of tax compliance (PerezTruglia \& Troiano, 2018). Because the use of shaming as an enforcement strategy is pervasive among tax administrators (OECD, 2019), a better understanding of shaming mechanisms may help curb tax evasion (Blank, 2009; OECD, 2019). Perez-Truglia and Troiano (2018) find that shaming has a positive effect on the payment of delinquent tax debts in the direction anticipated by policy makers. However, their "evidence comes from a tax delinquency setting, but shaming penalties may also be applied for other aspects of tax compliance, such as tax evasion and tax avoidance" (PerezTruglia \& Troiano, 2018, p. 133). Dwenger and Treber (2018) also investigate tax delinquency. Therefore, this study investigates shaming punishment of tax evaders to extend the literature on shaming to the tax evasion setting.

Second, this study adds to behavioral tax compliance research which emphasizes the use of non-pecuniary measures to enforce tax compliance. Previous studies suggest that governments are increasingly using behavioral strategies, such as nudge interventions, to change people's behaviors toward certain directions (Benartzi et al., 2017; Reisch \& Sunstein, 2016). Nudges include reminders and streamlined disclosure policies (Benartzi et al., 2017). According to Vainre et al. (2020), combining several behavioral interventions or nudges may be effective at changing tax evasion behaviors. Specifically, nudging, which involves intervention emails aimed at strengthening the perceived risk of being caught and fined, enhances the perception of fairness of the tax authority, weakens the descriptive norm of noncompliance, and improves tax compliance (Vainre et al., 2020). However, Vainre et al.'s (2020) study does not investigate nudging in the shaming context. Branham (2008, p. 1508) suggests that "To the extent that norms and other nonpecuniary elements factor into a taxpayer's decision to comply with or evade taxes", mass media may aid in tax enforcement efforts. Branham's study is normative, and it does not test any assertion. Unlike Garz and Pagels (2018), the current study focuses on the general public, not celebrities, and uses experiments with a randomized factorial design. This study also examines the link between the perceptions of retributive justice in shaming punishment and tax compliance intentions to add to research on the effects of perceived justice on tax compliance (Alm et al., 2020; Braithwaite et al., 2007; Jimenez \& Iyer, 2016; Kim, 2002; Kirchler et al., 2008; Murphy, 2009; Rechberger et al., 2010; Wenzel, 2002).

Finally, this study focusing on how observers react to the way others are treated has important implications for theory and practice. Theoretically, the results of the current 
work provide empirical evidence that shaming tax evaders has a general deterrence effect, which is consistent with the deterrence aspect of Sherman's (1993) defiance theory. Furthermore, this study has drawn from the Yale Model of Persuasion and Hasseldine et al.'s (2007) persuasive communication strategies to predict and find that higher persuasion is positively related to tax compliance intentions. The current study presents evidence that an integrative framing of punishment disclosures can improve tax compliance. This theoretical argument is consistent with that of Pelletier and Sharp (2008) on how persuasion could be used to promote pro-environmental behavior. From a practical perspective, this study demonstrates that shaming tax evaders using tax conviction notices could improve the perceptions of retributive justice and tax compliance intentions, which may be informative for tax authorities. This study contributes to the debate on the ethics of public shaming, and is relevant to tax authorities concerned about the morality of shaming or that believe considerable tax revenue will be lost without shaming tax evaders. The findings suggest that higher persuasion is an effective alternative to shaming. Tax noncompliance is a global problem that reduces funding for social security and infrastructure and exacerbates social inequality and unequitable distribution of the tax burden (Lipatov, 2012; Slemrod, 2019). Therefore, this study provides additional evidence regarding tax compliance interventions or nudges that are effective and have low implementation costs.

The remainder of the paper is outlined as follows. The next section develops the hypotheses. Section three describes the methodology, and section four presents the empirical results. Section five discusses the findings and conclusion of the study.

\section{Hypothesis Development}

\section{Shaming Tax Evaders to Promote Tax Compliance}

Garnering voluntary compliance has become increasingly important for tax compliance, and accounting research on how to use shaming to deter tax evasion may benefit from Sherman's (1993) defiance theory. This theory suggests that the effect of criminal sanctioning is diverse, and punishment may increase, reduce or have no effect on future crimes, which he termed the defiance, deterrence and irrelevance effects of criminal sanctions. Sherman's (1993) defiance theory combined Braithwaite's (1989) theory of reintegrative shaming, Tyler's (1990) procedural justice, and Scheff and Retzinger's (1991) shame and rage in destructive conflicts. Defiance theory further suggests that the deterrence effect of shaming punishment may counterbalance its defiance effect, making the effect of shaming tax evaders irrelevant. Because the treatment of others may affect observers (Skarlicki et al.,
1998), observers will likely be less compliant when they perceive shaming punishment to be inappropriate and more compliant when they perceive the punishment to be fair.

The media in Canada has claimed, sardonically, that the CRA acts more punitively toward poor taxpayers than affluent taxpayers, which echoes the finding in the Auditor General's report to the Parliament of Canada in 2018 that "the Canada Revenue Agency did not consistently apply tax rules when it audited or reviewed taxpayers' files, even though the Taxpayer Bill of Rights includes the right to have the law applied consistently" (Aiello, 2018; Government of Canada, 2018). This conclusion further suggests that if observers do not perceive the enforcement action of the tax authority in convicting and shaming other taxpayers to be fair, they may be less willing to cooperate with the tax authority or may become retaliatory. Conversely, observers who perceive the conviction and shaming of another taxpayer to be fair may be more willing to comply. Overall, based on extant research showing that nudging improves tax compliance (Vainre et al., 2020), shaming delinquent taxpayers enhances the collection of certain tax debts (Perez-Truglia \& Troiano, 2018), and celebrity shaming increases participation in tax amnesty programs (Garz \& Pagels, 2018), the following hypothesis is proposed:

H1 Shaming tax evaders is positively related to tax compliance intentions for third-party observers.

\section{Shaming Tax Evaders for Retributive Justice}

Justice is multifaceted and includes how resources are distributed or exchanged (distributive justice), the fairness of processes and procedures (procedural justice), the quality of interpersonal encounters and information provided (interactional justice), the appropriateness of sanctions and punishments for violations (retributive justice), and the rehabilitation of offenders and restoration of shared values (restorative justice) (Farrar et al., 2019; Jasso et al., 2016; Vermunt \& Steensma, 2016; Wenzel \& Okimoto, 2016; Wenzel et al., 2008). This study focuses on retributive justice because tax conviction notices contain the identities of convicted tax evaders and details of their crimes and sanctions and exclude the nuances of exchanges, procedures and interactions between convicted taxpayers and the tax authority. Retribution or just desserts is considered an appropriate philosophical or moral basis for punishment because it ensures that justice is served "through unilateral imposition of punishment" (Bradley, 2003; Rechberger et al., 2010; Wenzel \& Thielmann, 2006; Wenzel et al., 2008, p. 375). Retributive justice is a means of enforcing positive outcomes by imposing sanctions against offenders for their illegal actions (Wenzel \& Okimoto, 2016), and perceived retributive justice is 
observers' perceptions of the appropriateness of tax evader punishments.

Under the Canadian criminal code, the objectives of sanctions are to denounce unlawful conduct and the harm done to victims or the community caused by the offender, deter the offender and others from committing offenses, separate offenders from society (if necessary), assist in rehabilitating offenders, provide compensations for harm done to victims or the community, and promote a sense of responsibility among offenders (Department of Justice Canada, 2020). Human actions are guided by rationality and norms (Elster, 1989), and social norms "constrain behavior without the force of laws" (Cialdini \& Trost, 1998, p. 152). Therefore, the creation of effective norms around tax evasion punishment may be a low-cost method for tax authorities to curb tax evasion.

Skarlicki et al. (1998) indicate that uninvolved observers are likely to be affected by how others are treated, and they (uninvolved observers) use criteria similar to those of third parties to assess fairness. Therefore, punishing tax evaders by communicating to the public that evaders received the punishment that they deserved could affect observers' perceptions of retributive justice and have a deterrence effect. This effect could underlie a tax authority's decision to publicize tax conviction notices. Taxpayers typically learn about shamed tax evaders from mass media sources, including newspapers and news releases. Although these media notices may signal to taxpayers that the government cares about tax evasion, it is important to investigate how the wider public perceives the shaming of tax evaders. Consistent with the objectives of punishment and extant research showing that punishment influences perceived retributive justice (Beccaria, 2009; Okimoto \& Wenzel, 2009), the following hypothesis is proposed:

H2 The shaming of tax evaders is positively related to the perceptions of retributive justice for third-party observers.

\section{Interaction Effects of Shaming and Persuasion}

Although tax authorities have continued to use traditional methods as tax enforcement techniques including audits, incarcerations, penalties, shaming and third-party reporting requirements, the authorities have increasingly deployed persuasive communications to alter taxpayer perceptions of tax evasion and increase voluntary compliance (Alm \& Torgler, 2011; Devos \& Zackrisson, 2015). Previous tax literature has examined the success of using persuasive communications to improve tax compliance but reported mixed results (Blumenthal et al., 2001; Hasseldine et al., 2007; Perez-Truglia \& Troiano, 2018). For example, Blumenthal et al. (2001) and Perez-Truglia and Troiano (2018) find that moral appeal is not an effective mechanism to reduce tax evasion. In contrast,
Hasseldine et al. (2007, p. 171) find, based on controlled field experiments involving a sample of 7307 taxpayers in the UK, that normative and sanction appeals from a national tax agency led to increased levels of reported sales and net income for sole proprietors. The tax agency's normative appeal letter contains "positive reasons why compliance is advantageous", and sanction appeals emphasize "the negative consequences of noncompliance". Therefore, tax authorities could rely on the use of sanctions (Hasseldine et al., 2007; Violette, 1989), morality or educational communications (Hasseldine et al., 2007; Kaplan et al., 1997) to persuade taxpayers. Following Hasseldine et al. (2007), the terms sanction appeals and normative appeals are used throughout this paper. Unlike previous studies on persuasion, the present study examines the shaming punishments of tax evaders.

The origin of the "scientific study of persuasion" can be attributed to Hovland et al.'s Message Learning Model, which is also termed the Yale Model of Persuasion (Cameron, 2009, p. 310; Hovland et al., 1953). The model suggests that for a message to be persuasive, it must gain the attention of the recipient, be understandable, raise questions in the recipient's mind, provide incentives for attitudinal change, and contain information that may be recalled by the recipient (Cameron, 2009; Hovland et al., 1953). Consequently, tax authorities may draw on the model to construct persuasive messages that achieve the desired communication effects on taxpayers, including changes in beliefs, attitudes and behaviors. Previous studies have shown that the tendency of taxpayers to cooperate and pay their taxes is conditional upon the actions and behaviors of tax authorities and other taxpayers (e.g., Farrar et al., 2019; Frey \& Torgler, 2007; Gangl et al., 2013). An interesting question is whether observers become more compliant when the tax authority uses persuasive messages when shaming convicted tax evaders. It is also relevant to elucidate what constitutes higher persuasion in written communications involving shaming, and whether sanction appeals or normative appeals are more effective in persuading third-party observers when shaming tax evaders. This discussion leads to the following hypotheses related to interactions of shaming and persuasion:

H3a The effect of shaming tax evaders on third-party observers' tax compliance intentions will be stronger under higher persuasion than under lower persuasion.

H3b The effect of shaming tax evaders on observers' perceptions of retributive justice will be stronger under higher persuasion than under lower persuasion.

H3c Providing observers with sanction appeals, rather than normative appeals, while shaming tax evaders is positively related to observers' tax compliance intentions. 


\section{Effect of Perceived Retributive Justice on Tax Compliance Intentions}

Several studies have suggested that taxpayers' perceptions of retribution are a relevant factor in explaining compliance decisions (e.g., Bergman, 2003; Braithwaite et al., 2007; Kirchler et al., 2008; Okimoto \& Wenzel, 2009; Rechberger et al., 2010; Wenzel \& Okimoto, 2016; Wenzel \& Thielmann, 2006). When the tax authority exercises power, taxpayers are less likely to dismiss these acts as irrelevant due to fear of retribution (Braithwaite et al., 2007). Moreover, "credible sanctions" that are consistently implemented under legitimate power increase trust in authority and tax compliance intentions (Bergman, 2003; Kirchler et al., 2008, p. 213). In contrast, inconsiderate uses of power and perceived retributive injustice increase distrust and tax noncompliance (Kirchler et al., 2008). These observations suggest that observers' perceptions of retributive justice in tax evader punishments may have a positive effect on tax compliance intentions. Therefore, the following hypothesis is proposed:

H4 Third-party observers' perceptions of retributive justice in tax evader punishments is positively related to their tax compliance intentions.

\section{Does Shaming Have an Indirect Effect on Tax Compliance Intentions?}

In $\mathrm{H} 1$ and $\mathrm{H} 2$, this study predicts that shaming should be positively related to tax compliance intentions and perceptions of retributive justice, respectively, for third-party observers. $\mathrm{H} 3 \mathrm{a}, \mathrm{H} 3 \mathrm{~b}$ and $\mathrm{H} 3 \mathrm{c}$ also predict the same positive effects of shaming on perceptions of retributive justice and tax compliance intentions, moderated by persuasion. In H4, this study further predicts that perceptions of retributive justice should have a direct positive relationship with tax compliance intentions. Thus, the prior hypotheses in this study test direct and moderation effects. However, they do not test the indirect effect of shaming on tax compliance intentions. An indirect effect occurs when the effect of an independent variable on a dependent variable is mediated by a third variable (mediator) (Biesanz et al., 2010; Edwards \& Lambert, 2007; Shrout \& Bolger, 2002). Therefore, mediation relates to the intervening variables that produce the effect (Muller et al., 2005). It is common to specify indirect effects in the social sciences (Biesanz et al., 2010) and mediation analyses are useful for understanding the mechanisms of effects and developing theories in behavioral psychology (Abu-Bader \& Jones, 2021; Baron \& Kenny, 1986; MacKinnon et al., 2007, 2012). Because shaming can affect both the perceptions of retributive justice and tax compliance intentions, and the perceptions of retributive justice can affect the compliance intentions, it is important to explore whether perceptions of retributive justice mediate the effect of shaming on tax compliance intentions. Based on this discussion, the following final hypothesis is proposed:

H5 Perceptions of retributive justice mediate the effect of shaming on tax compliance intentions.

Below is Fig. 1 which presents the hypothesized relationships.

\section{Methodology}

\section{Participants and Recruitment}

Participants in the two experiments of this study were Canadian taxpayers recruited by an experienced professional multinational survey organization-Dynata. Participants in the first experiment were blocked from participating in the second experiment. The Ryerson University Research Ethics Board reviewed and approved the study and experimental instruments prior to participant recruitment. Taxpayers between 21 and 80 years old were eligible to participate, and the survey organization made efforts to randomly select participants and evenly distribute them across age groups, with a 50/50 sex split. Data collection was terminated when 300 complete responses were received for each experiment. Because response time and outliers are notable indices of careless survey responses (Meade \& Craig, 2012), the company ensured that participants with outlier responses and participants completing the experiment too quickly or too slowly were eliminated. Specifically, participants who completed the survey in two minutes or less and those who took over an hour to complete the survey were eliminated and replaced.

Survey data are subject to social desirability bias, and the bias is higher when respondents encounter unethical situations or sensitive constructs (Chung \& Monroe, 2003; King \& Bruner, 2000). To address social desirability bias, the participants were guaranteed anonymity (Chung \& Monroe, 2003; Otaye-Ebede et al., 2020). A third-person measure was also used for tax compliance intentions and the perception of retributive justice of shaming punishments because a first-person measure of unethical or illegal behavior may lead to social desirability bias (Mascagni, 2018). Stated differently, indirect questioning reduces social desirability bias. According to Fisher (1993, p. 307), "no systematic upward or downward bias resulted from asking subjects to make predictions about typical others as opposed to making 


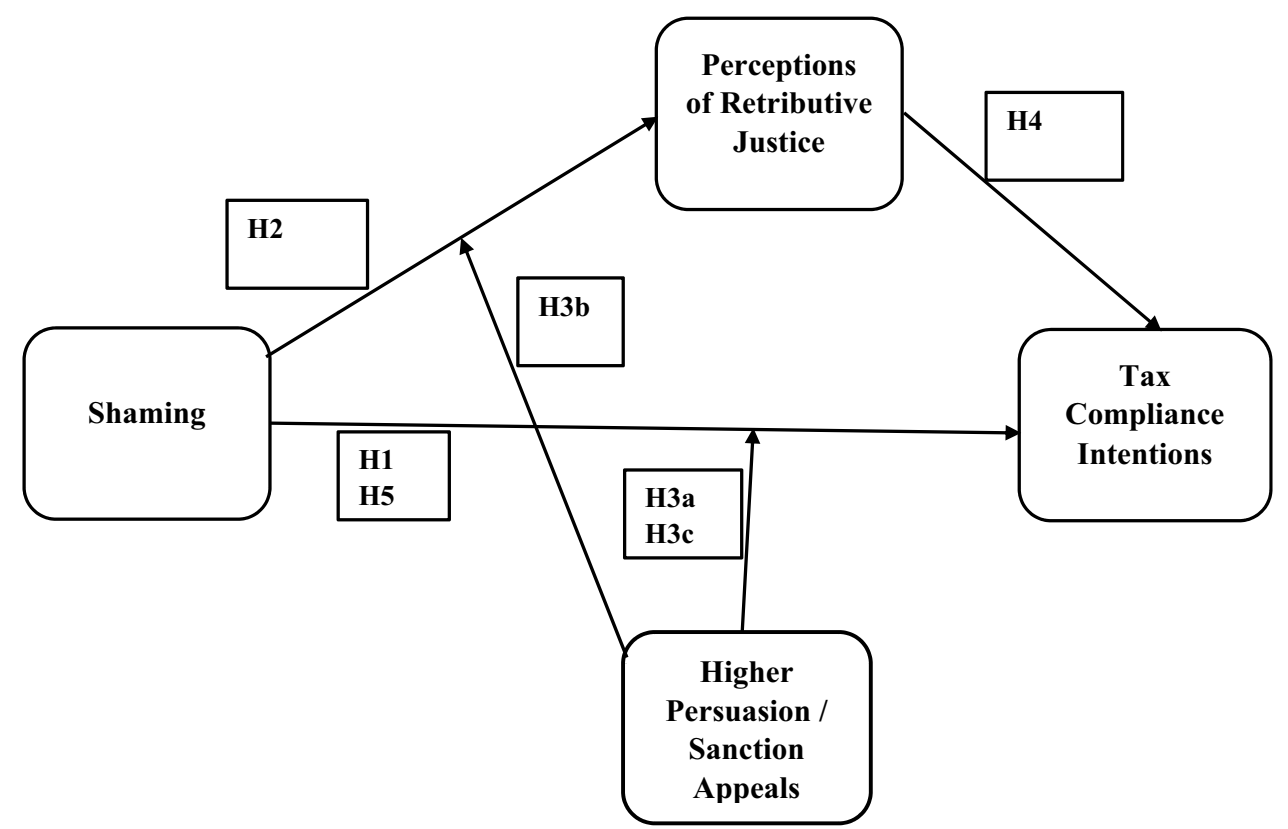

Fig. 1 The hypothesized relationships. Graphically presents the hypothesized relationships. $\mathrm{Hl}$ is the hypothesized direct effect of shaming on tax compliance intentions; $H 2$ is the hypothesized direct effect of shaming on perceptions of retributive justice; $H 3 a \& H 3 c$ are the hypothesized direct effects of shaming on tax compliance intentions, moderated by higher persuasion (Experiment 1) and sanc- tion appeals (Experiment 2), respectively; $H 3 b$ is the hypothesized direct effect of shaming on perceptions of retributive justice, moderated by higher persuasion; $H 4$ is the hypothesized direct effect of perceptions of retributive justice on tax compliance intentions; $H 5$ is the hypothesized indirect effect of shaming on tax compliance intentions

2013; Falk \& Heckman, 2009; Viceisza, 2016). These studies call for more laboratory experiments in the social sciences. The current study used experimental case scenarios and the Likert scale due to the difficulty of directly assessing how tax evaders react to shaming. Although the scenario approach has some limitations, it is a feasible approach to measure respondents' perceptions or intentions (Farrar et al., 2019; Latan et al., 2021). It can be argued that laboratory experiments using questionnaires and the Likert scale provide control over extraneous and independent variables and the investigation of cause and effect relationships in ways that may be difficult or infeasible in field experiments. For example, it may be impracticable to randomize shaming punishments for tax evaders in a field experiment setting due to legal restrictions or other reasons, which may mean that tax offenders are punished differently for the same crime. Cronbach's alpha was also used to measure the reliability or internal consistency of the collected Likert data. Regarding whether laboratory tax compliance experiments are externally valid, Alm et al. (2015, p. 1170) suggest that laboratory experiments inform policy debates because "the behavioral patterns of subjects in the laboratory conform to those of individuals making a similar decision in naturally occurring settings". Compared to telephone interviews, laboratory experiments exhibit higher concurrent and predictive validity and lower measurement error (Chang \& Krosnick,

$\overline{1}$ Age and sex are included in the participant selection criteria. 
Table 1 Demographic characteristics of the participants

\begin{tabular}{|c|c|c|c|c|c|c|c|c|}
\hline & \multicolumn{4}{|c|}{ Experiment 1} & \multicolumn{4}{|c|}{ Experiment 2} \\
\hline & Mean & SD & $\mathrm{N}$ & Percent & Mean & SD & $\mathrm{N}$ & Percent \\
\hline & 49.65 & 14.73 & & & 49.24 & 15.46 & & \\
\hline \multicolumn{9}{|l|}{ Age } \\
\hline $21-34$ & & & 60 & 20 & & & 60 & 20 \\
\hline $35-44$ & & & 60 & 20 & & & 60 & 20 \\
\hline $45-54$ & & & 60 & 20 & & & 60 & 20 \\
\hline $55-64$ & & & 60 & 20 & & & 60 & 20 \\
\hline $65-80$ & & & 60 & 20 & & & 60 & 20 \\
\hline \multicolumn{9}{|l|}{ Sex } \\
\hline Male & & & 147 & 49 & & & 150 & 50 \\
\hline Female & & & 150 & 50 & & & 150 & 50 \\
\hline Prefer not to specify & & & 3 & 1 & & & 0 & 0 \\
\hline \multicolumn{9}{|l|}{ Education } \\
\hline Less than high school & & & 6 & 2 & & & 3 & 1 \\
\hline High school & & & 82 & 27.3 & & & 82 & 27.3 \\
\hline Associate's degree & & & 51 & 17 & & & 50 & 16.7 \\
\hline Bachelor's degree & & & 88 & 29.3 & & & 95 & 31.7 \\
\hline Master's degree & & & 28 & 9.3 & & & 26 & 8.7 \\
\hline $\begin{array}{l}\text { Doctoral degree/Profes- } \\
\text { sional degree }\end{array}$ & & & 20 & 6.7 & & & 17 & 5.6 \\
\hline Other & & & 25 & 8.3 & & & 27 & 9 \\
\hline \multicolumn{9}{|l|}{ Annual income } \\
\hline Under $\$ 25,000$ & & & 50 & 16.7 & & & 52 & 17.3 \\
\hline$\$ 25,000-49,999$ & & & 71 & 23.7 & & & 78 & 26 \\
\hline$\$ 50,000-74,999$ & & & 54 & 18 & & & 64 & 21.3 \\
\hline$\$ 75,000-99,999$ & & & 60 & 20 & & & 48 & 16 \\
\hline Over $\$ 100,000$ & & & 41 & 13.7 & & & 44 & 14.7 \\
\hline Prefer not to answer & & & 24 & 8 & & & 14 & 4.7 \\
\hline \multicolumn{9}{|l|}{ Religiosity } \\
\hline 1 Not religious & & & 98 & 32.7 & & & 92 & 30.7 \\
\hline 22 & & & 32 & 10.7 & & & 30 & 10 \\
\hline 33 & & & 13 & 4.3 & & & 20 & 6.7 \\
\hline 44 & & & 48 & 16 & & & 38 & 12.7 \\
\hline 55 & & & 60 & 20 & & & 49 & 16.3 \\
\hline 66 & & & 27 & 9 & & & 42 & 14 \\
\hline 7 Very religious & & & 22 & 7.3 & & & 29 & 9.6 \\
\hline Sample size & & & 300 & 100 & & & 300 & 100 \\
\hline
\end{tabular}

2010). Two experienced behavioral tax researchers reviewed the instruments and questionnaire, and provided feedback.

Using two between-subjects experiments, participants in each experiment were assigned to one of four experimental conditions. The stimuli were news releases about convictions of tax evaders and persuasive messages from a tax authority. The participants in all four conditions (shaming by salience of persuasion) were asked to carefully read, as taxpayers, a news release by the CRA for Canadian taxpayers and respond to some follow-up questions.

\section{Shaming}

Shaming was measured as present or absent by including or excluding information on a convicted tax evader and details on the evader's crimes and punishments. For the presence of shaming conditions, the following excerpt from a news release adapted from a conviction notice in the CRA database was used:

The Canada Revenue Agency (CRA) has announced that Carlos Brown of Toronto, Ontario, was convicted on August 27, 2020, in the Provincial Court of Ontario, 
of one count of tax evasion under the Income Tax Act, and one count of tax evasion under the Excise Tax Act. Mr. Brown was ordered to serve a 12-month conditional sentence, and was fined a total of $\$ 157,403$.

The scenario also provided information on Carlos' crime, how it was carried out, and the usual enforcement message that "Tax evasion is a crime...". This shaming scenario was constructed based on the expectation that when observers read the name, city, crimes, and punishments of a convicted tax evader, they may experience a feeling of uneasiness or shame that would occur if they were Carlos. As previously discussed, observers may be affected by how others are treated, and they (observers) use similar criteria as third parties to process information (Skarlicki et al., 1998). Conversely, participants in the absence of shaming conditions were provided with only the usual enforcement message of tax authority adapted from a publication in the CRA database:

Tax evasion is a crime. Falsifying records and claims, willfully not reporting income, or inflating expenses can lead to criminal charges, prosecution, jail time, and a criminal record. From April 1, 2019, to March 31,2020 , there were 32 convictions, with 13 taxpayers sent to jail for a total of 18.5 years. These individuals were sentenced for willfully evading payment of $\$ 7,427,090$ in tax.

In this no-shaming scenario, no tax evader was named, and no tax crime or punishment was discussed. The same shaming measure was used for the two experiments.

\section{Persuasion}

The salience of persuasion of the shaming punishment contents publicized by the tax authority was operationalized differently for Experiments 1 and 2. For Experiment 1 , persuasion was a binary variable taking the values of higher or lower. Under the higher persuasion condition, the scenario was based on Hasseldine et al. (2007) and included sanction and normative appeals:

Most people in this country pay their proper taxes. But even small mistakes by a lot of people can add up to a lot of lost tax and, therefore, less money available for public spending on things like hospitals, schools and pensions. The CRA is substantially increasing the number of enquiries into the tax returns of taxpayers, and your return may be one of those chosen for inquiry.

Hasseldine et al. (2007) find these appeals persuasive and identify sanction appeals as more persuasive than normative appeals in a no-shaming setting. Moreover, information on voluntary disclosure programs (VDPs) was included to inform observers that they would have a second chance to correct their tax returns through the VDPs. These messages were added based on the expectation that they would influence and incentivize observers to pay their taxes (Hovland et al., 1953). The messages were operationalized to provide observers positive reasons why tax compliance is important and simultaneously cause them to feel that they may be selected for an inquiry that could lead to prosecution. In contrast, participants under the lower persuasion condition were provided only a normative appeal.

Most people in this country pay their proper taxes. But even small mistakes by a lot of people can add up to a lot of lost tax and, therefore, less money available for public spending on things like hospitals, schools and pensions.

This message did not include Hasseldine et al.'s (2007) sanction appeals or draw on Hovland et al.'s (1953) message learning model to provide incentives for compliance. For Experiment 2, sanction appeals were separated from normative appeals. The rationale for this construction of persuasion in the second experiment was partially to provide additional evidence on whether the content of written messages in a tax conviction notice affects compliance intentions and whether sanction appeals are more persuasive than normative appeals in the shaming context. Shaming and persuasion are the main independent variables in this study. These scenarios are available as supplementary data.

\section{Tax Compliance Intentions}

As dependent variable, tax compliance intentions were measured using a 5-item scale adapted from Farrar et al. (2019, 2020). Sample items include "Taxpayers will report their income on their tax returns even if the party paying them does not report the payment to the CRA", "Taxpayers will not overstate their tax deductions on their tax returns even if the amounts are paid in cash" and "Taxpayers will file their tax returns even if they know the CRA has no way of knowing". In particular, Farrar et al. (2019) used a similar scale to measure taxpayers' compliance intentions. Therefore, to reduce bias, observers' perceptions of others' tax compliance behaviors may be used to measure the tax compliance intentions of the observers (Ali et al., 2014; Farrar et al., 2019, 2020; Taing \& Chang, 2021). The measure was based on a 7-point Likert-type scale that ranged from $1=$ strongly disagree to $7=$ strongly agree. The Cronbach's alpha reliability was 0.91 , which indicates acceptable reliability. 
Table 2 Experiment 1 manipulation checks and outcomes

\begin{tabular}{lccccccccc}
\hline & Mean & $N$ & SD & SS & DF & MS & $F$ & $P$ & $\eta^{2}$ \\
\hline Shaming & 5.08 & 150 & 1.67 & & & & & & \\
No shaming & 3.45 & 150 & 1.95 & & & & & & \\
Difference between means & & & & 198.45 & 1 & 198.45 & 60.21 & 0.00 & 0.17 \\
Higher persuasion & 5.17 & 150 & 1.55 & & & & & & \\
Lower persuasion & 4.07 & 150 & 1.77 & & & & & & \\
Difference between means & & & & 90.75 & 1 & 90.75 & 32.83 & 0.00 & 0.10 \\
\hline
\end{tabular}

Shaming manipulation (CRA publicizes names of convicted tax evaders) was successful at $p<0.01$, and the effect size was large $\left(\eta^{2}=0.17\right)$. Persuasion manipulation (taxpayers would be persuaded by this message from the CRA) was also successful at $p<0.01$, and the effect size was medium $\left(\eta^{2}=0.10\right)$

Both measures were based on a 7-point Likert-type scale ranging from $1=$ do not agree at all to $7=$ totally agree

\section{Perceptions of Retributive Justice}

The perceptions of retributive justice were assessed using a 4-item scale. The participants were asked to think about the news release and rate their perceptions of the appropriateness of punishments for tax evaders. The following four items were assessed: (1) Taxpayers would agree that punishments of tax evaders in Canada reflect the severity of the evaders' wrongdoing; (2) Canadians would think that sanctions of tax evaders by the CRA fit the tax crimes; (3) People in Canada think that tax evaders deserve to be sentenced by authorities; and (4) Canadians would think that tax evaders are appropriately fined by tax authorities. The measurement scale ranged from $1=$ strongly disagree to $7=$ strongly agree and had a Cronbach's alpha of 0.89 , which indicates acceptable reliability.

\section{Results}

This section first presents preliminary analyses consisting of manipulation outcomes, a correlation matrix and descriptive statistics (group means and standard deviations). It subsequently presents the results of hierarchical multiple regression models that test hypotheses 1-4. Multiple regression analysis is highly flexible for examining relationships of quantitative or categorical (e.g., treatment conditions in an experiment) independent variables to a dependent variable (Aiken et al., 2003). Hierarchical multiple regression models allow variables to be added to the models in steps to indicate the relative importance of the predictor variables (Radmacher \& Martin, 2001; Skarlicki et al., 1998). Hierarchical regression analysis is appropriate for testing direct relationships and their moderations (Kim et al., 2005; Pierce et al., 1993). In other words, a hierarchical regression model shows how the addition of predictor variables improves the model's ability to explain the outcome variables. The last part of this section provides evidence on the indirect effects of shaming on tax compliance intentions (hypothesis 5). There are inference problems associated with using hierarchical multiple regression to test mediating effects (Stone-Romero \& Rosopa, 2004), but the Hayes process uses bootstrapping to lower the risk of false rejection of null hypothesis (AbuBader \& Jones, 2021; Hayes, 2018). In addition, this study considered the discussions on mediation analysis provided by Baron and Kenny (1986), MacKinnon et al. (2012) and Hayes (2018), and then used Hayes PROCESS Model 4 to investigate the indirect effect of shaming on compliance intentions. Although analyses of variance (ANOVAs) were performed in the preliminary analyses, and results indicated that there were significant differences in perceptions of retributive justice and tax compliance intentions among groups of observers exposed to different nudges and that the effect sizes of shaming and persuasion were small, the ANOVA results are not discussed for readability and parsimony, and because they do not test the hypothesized relationships or provide additional evidence to support the results of the hierarchical regression analyses. ${ }^{2}$

\section{Experiment 1}

\section{Preliminary Analyses}

\section{Manipulation Checks and Outcomes}

To determine whether shaming manipulation was effective, the participants were asked to indicate their level of agreement with the following statement: "The CRA publicizes the names of convicted tax evaders". Similarly, as a manipulation check for persuasion, participants were asked to indicate their level of agreement with the statement that taxpayers will be persuaded by the nudge from the CRA.

\footnotetext{
$\overline{2}$ The author thanks an anonymous reviewer for comments on methodology.
} 
Table 3 Experiment 1 correlation matrix

\begin{tabular}{lcclllll}
\hline & Mean & SD & 1 & 2 & 3 & 4 & 5 \\
\hline Tax compliance intentions (1) & 4.538 & 1.395 & 1 & & & \\
Perceptions of retributive justice (2) & 5.034 & 1.337 & $0.527^{* * *}$ & 1 & & & \\
Shaming (3) & 0.50 & 0.501 & $0.151^{* *}$ & $0.168^{* * *}$ & 1 & & \\
Persuasion (4) & 0.50 & 0.501 & $0.100^{*}$ & -0.013 & 0.000 & 1 & \\
Age (5) & 49.65 & 14.728 & $-0.108^{*}$ & $0.133^{* *}$ & -0.063 & 0.048 & 1 \\
Religiosity (6) & 3.36 & 2.059 & $0.106^{*}$ & 0.046 & 0.086 & -0.005 & -0.033 \\
\hline
\end{tabular}

Pearson's correlation coefficients are indicated above

***The correlation is significant at the 0.01 level (2-tailed)

**The correlation is significant at the 0.05 level (2-tailed)

*The correlation is significant at the 0.1 level (2-tailed)

Dependent variable: Tax compliance intentions was measured as the average of a participant's scores for the following five statements, based on a 7-point Likert scale ( $1=$ strongly disagree to $7=$ strongly agree). (a) Taxpayers will report their income on their tax returns even if the party paying them does not report the payment to the CRA. (b) Taxpayers will report their income on their tax returns even if they receive the income in cash. (c) Taxpayers will not overstate their tax deductions on their tax returns even if the amounts are paid in cash. (d) Taxpayers will not overstate tax deductions on their tax returns even if they know the CRA has no way of checking the amount. (e) Taxpayers will file their tax returns even if they know the CRA has no way of knowing

Independent variables: Shaming was coded as 1 for presence and 0 for absence. Persuasion was coded as 1 for higher and 0 for lower persuasion Covariates: Age is the participant age in years (participants were equally distributed across age brackets from 21 to 80 ). Religiosity is the participant's score on the following question: How would you rank your religious beliefs on a scale of 1 to 7 , with $1=$ not religious and $7=$ very religious?

The variable-Perceptions of retributive justice was measured as the average of a participant's scores for the following four statements, based on a 7-point Likert scale $(1=$ strongly disagree to $7=$ strongly agree). (a) Taxpayers would agree that punishments of tax evaders in Canada reflect the severity of the evaders' wrongdoing. (b) Canadians would think that sanctions of tax evaders by the CRA fit the tax crimes. (c) People in Canada would think that tax evaders deserve to be sentenced by authorities. (e) Canadians would think that tax evaders are appropriately fined by tax authorities

Both measures were based on a 7-point Likert-type scale that ranged from $1=$ do not agree at all to $7=$ totally agree.

The manipulation checks for shaming and persuasion were successful, and the outcomes are presented in Table 2 below. The mean response was $5.08(\mathrm{SD}=1.67)$ for the shaming condition and $3.45(\mathrm{SD}=1.95)$ for the no-shaming condition. The difference between the two means was significant $(F(1,298)=60.21, p<0.01)$, and the means were in the expected direction. The participants reported higher shaming when they read the tax conviction notice that included shaming of a tax evader. Similarly, the mean responses for the higher and lower persuasion conditions were $5.17(\mathrm{SD}=1.55)$ and $4.07(\mathrm{SD}=1.77)$, respectively. The participants reported higher persuasion when sanction appeals, normative appeals and incentives for compliance were combined and used, than when only normative appeals were used $(F(1,298)=32.83, p<0.01)$.

\section{Correlation Matrix}

Correlations between tax compliance intentions, perceptions of retributive justice, shaming, persuasion and controls were examined using a Pearson correlation matrix. Table 3 presents the correlation matrix for variables with a significant correlation. The correlation between compliance intentions and shaming is positive and significant $(r=0.15, p<0.05)$. This indicates that tax compliance intentions are likely stronger in the presence of shaming conditions than when shaming is absent. The correlation between compliance intentions and persuasion is also positive and marginally significant $(r=0.10, p<0.10$ ), which suggests that compliance intentions are likely stronger under higher persuasion than lower persuasion. Furthermore, there is a negative and marginally significant correlation between compliance and age $(r=-0.11, p<0.10)$, which suggests that younger people perceive tax compliance differently than older people. Compliance intentions and religiosity also have a positive and marginally significant correlation $(r=0.11, p<0.10)$, which indicates that being more religious is likely associated with stronger tax compliance intentions. These results are consistent with Boone et al. (2013).

There is a positive and significant correlation between perceptions of retributive justice and shaming $(r=0.17$, $p<0.01)$. Perceptions of retributive justice and tax compliance intentions also have a positive and significant correlation $(r=0.53, p<0.01)$. This result suggests that observers who see shaming punishments of tax evaders as appropriate and deserving may have higher intentions to comply. The correlation between perceptions of retributive justice and age is positive and significant $(r=0.13, p<0.05)$, which 
Table 4 Experiment 1 mean tax compliance intentions per experimental condition

\begin{tabular}{|c|c|}
\hline Condition & $\begin{array}{l}\text { Tax compli- } \\
\text { ance inten- } \\
\text { tions }\end{array}$ \\
\hline \multicolumn{2}{|c|}{ Shaming and higher persuasion } \\
\hline Mean & 4.749 \\
\hline $\mathrm{SD}$ & 1.414 \\
\hline$N$ & 75 \\
\hline \multicolumn{2}{|c|}{ Shaming and lower persuasion } \\
\hline Mean & 4.747 \\
\hline SD & 1.333 \\
\hline$N$ & 75 \\
\hline \multicolumn{2}{|l|}{ Total } \\
\hline Mean & 4.748 \\
\hline SD & 1.369 \\
\hline$N$ & 150 \\
\hline \multicolumn{2}{|c|}{ No shaming and higher persuasion } \\
\hline Mean & 4.605 \\
\hline SD & 1.337 \\
\hline$N$ & 75 \\
\hline \multicolumn{2}{|c|}{ No shaming and lower persuasion } \\
\hline Mean & 4.051 \\
\hline SD & 1.403 \\
\hline$N$ & 75 \\
\hline \multicolumn{2}{|l|}{ Total } \\
\hline Mean & 4.328 \\
\hline SD & 1.394 \\
\hline$N$ & 150 \\
\hline
\end{tabular}

indicates that older observers may be more inclined to see shaming punishments as appropriate, which could lead to greater trust in the tax authority. Correlation does not imply causation (Rohrer, 2018), and no other variable significantly correlated with the perceptions of retributive justice and tax compliance intentions. Therefore, age and religiosity were included as control variables in subsequent analyses.

\section{Descriptive Statistics}

Table 4 shows the means and standard deviation of tax compliance intentions for each of the four experimental conditions: observing other tax evaders' shaming punishments and higher persuasion, $M=4.75, S D=1.41$; observing other tax evaders' shaming punishment and lower persuasion, $M=4.75, S D=1.33$; no shaming of other tax evaders and higher persuasion, $M=4.61, S D=1.34$; and no shaming of other tax evaders and lower persuasion, $M=4.05$, $S D=1.40$. The mean score for the two groups of observers in the "shaming" scenario was approximately equal, which suggests that the combining of shaming with higher persuasion, rather than lower persuasion, may not have any incremental value. Participants who observed shaming punishments rated significantly higher tax compliance intentions on average than participants who did not observe shaming punishment $(p<0.01)$.

\section{Hypothesis Tests}

\section{Tax Compliance Intentions}

Hierarchical multiple regression was used to test the hypothesized direct and moderation effects of shaming and persuasion on tax compliance intentions. The predictor variables were entered in three steps to sequentially capture the main effects of shaming and persuasion (step 1), their interaction effects (step 2), and the effects of perceived retributive justice and control variables (step 3). Skarlicki et al. (1998) use a similar approach to analyze data from their experiments. Moreover, Dawson (2014) recommends entering the interaction term in

Table 5 Hierarchical regression analysis of the effects of shaming and persuasion on tax compliance intentions

\begin{tabular}{|c|c|c|c|c|c|c|c|c|c|}
\hline \multirow[t]{2}{*}{ Variable } & \multicolumn{3}{|l|}{ Step 1} & \multicolumn{3}{|l|}{ Step 2} & \multicolumn{3}{|l|}{ Step 3} \\
\hline & $B$ & SE & $t$ & $B$ & SE & $t$ & $B$ & SE & $t$ \\
\hline Shaming & 0.420 & 0.159 & $2.642 * * *$ & 0.696 & 0.224 & $3.106 * * *$ & 0.289 & 0.191 & 1.509 \\
\hline Persuasion & 0.279 & 0.159 & $1.753^{*}$ & 0.555 & 0.224 & $2.476 * *$ & 0.493 & 0.188 & $2.622 * * *$ \\
\hline Shaming $\times$ Persuasion & & & & -0.552 & 0.317 & $-1.742 *$ & -0.338 & 0.266 & -1.271 \\
\hline Retributive Justice & & & & & & & 0.562 & 0.051 & $10.996 * * *$ \\
\hline Age & & & & & & & -0.017 & 0.005 & $-3.711 * * *$ \\
\hline Religiosity & & & & & & & 0.047 & 0.032 & 1.464 \\
\hline
\end{tabular}

$R^{2}=0.033$ for Step $1 ; \Delta R^{2}=0.010$ for Step $2 ;$ and $\Delta R^{2}=0.292$ for Step 3

$*_{p}<0.10 ; * * p<0.05 ; * * * p<0.01$

Adjusted $R^{2}=0.32$

Tax compliance intentions were measured as defined in Table 3. Ninety percent level of confidence was used (Farrar et al., 2019; Steiger, 2004). Other variables are defined in Table 3 


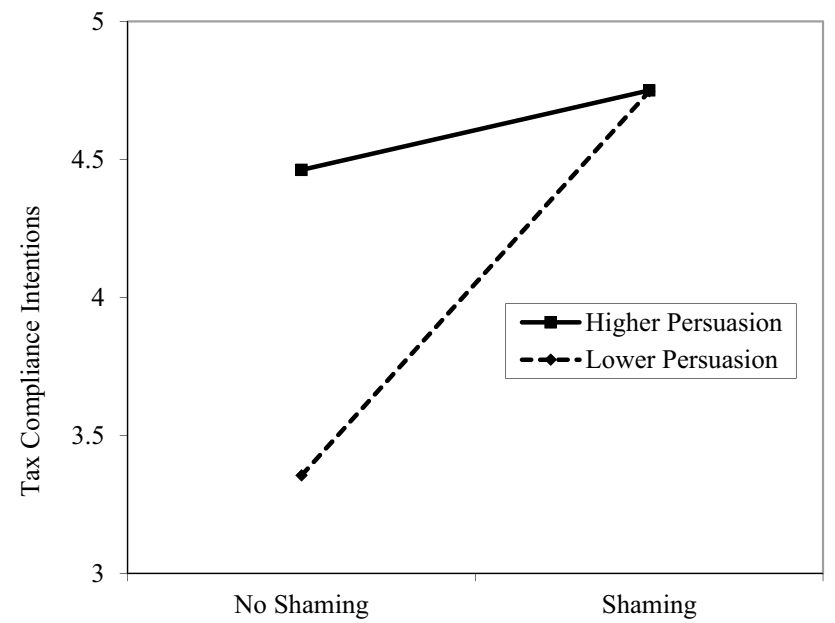

Fig. 2 The interactive effect of shaming and persuasion (higher vs lower) on tax compliance intentions. Shows tax compliance intentions relative to shaming tax evaders (shaming versus no shaming), salience of persuasion of observers (higher persuasion versus lower persuasion), and their two-way interaction based on hierarchical regression results from Experiment 1 . The dependent variable is tax compliance intentions. All variables are defined in Table 3

a separate step to permit computing the change in $R^{2}$. Steps 1 to 2 in Table 5 shows that shaming of tax evaders has a significant effect on tax compliance intentions. The coefficients of shaming are positive and significant at $p<0.01$ across the two steps, which indicates that Hypothesis 1 is supported. The results also show that observers under the higher persuasion condition had significantly stronger compliance intentions than observers under the lower persuasion condition.

The two-way interaction between shaming and persuasion is marginally significant and negative $(t=-1.74, p<0.10)$, which suggests that while the combined effect of shaming and higher persuasion may substantially influence tax compliance intentions, its impact is lower than the sum of the individual effects of shaming and higher persuasion.
Figure 2 graphically presents these results. It shows that higher persuasion is substantially more effective in the noshaming context, but not in the shaming context. Therefore, the tax authority may use normative appeals when shaming tax evaders and achieve similar results. Alternatively, the tax authority may use higher persuasion without shaming. These results do not support Hypothesis 3a.

The main effect of shaming became insignificant after perceptions of retributive justice and control variables were added to the regression model in Step 3 of the hierarchical model, and the coefficient of perceptions of retributive justice is positive and significant $(t=11.00, p<0.01)$, which suggests that perceptions of retributive justice appear to mediate the effect of shaming on intended tax compliance. This study uses the PROCESS macro to probe the mediation effect in the next sub-section. This result also indicates that third-party observers' perceptions of retributive justice in tax evader punishments are positively related to their intended tax compliance, which is consistent with previous studies (e.g., Rechberger et al., 2010; Wenzel \& Okimoto, 2016; Wenzel \& Thielmann, 2006). Therefore, Hypothesis 4 is supported. The coefficient of age (a control variable) is negative and significant, but this result must be interpreted with caution. The result suggests that intended tax compliance is lower among older observers than younger observers, but this finding may also reflect each group's (older versus younger observers) knowledge and perceptions of tax compliance. For example, younger people may feel that most people are tax compliant. The adjusted $R^{2}$ increased from 0.03 in Step 1 to 0.32 in Step 3.

\section{Perceptions of Retributive Justice}

Hierarchical regression analysis was also used to examine the effects of shaming and persuasion on observers' perceptions of retributive justice. As shown in Table 6, the

Table 6 Hierarchical regression analysis of the effects of shaming and persuasion on perceptions of retributive justice

\begin{tabular}{|c|c|c|c|c|c|c|c|c|c|}
\hline \multirow[t]{2}{*}{ Variable } & \multicolumn{3}{|l|}{ Step 1} & \multicolumn{3}{|l|}{ Step 2} & \multicolumn{3}{|l|}{ Step 3} \\
\hline & $B$ & SE & $t$ & $B$ & SE & $t$ & $B$ & SE & $t$ \\
\hline Shaming & 0.448 & 0.153 & $2.937 * * *$ & 0.610 & 0.216 & $2.826^{* * *}$ & 0.631 & 0.215 & $2.930 * * *$ \\
\hline Persuasion & -0.035 & 0.153 & -0.229 & 0.127 & 0.216 & 0.587 & 0.112 & 0.214 & 0.522 \\
\hline Shaming $\times$ Persuasion & & & & -0.323 & 0.305 & -1.059 & -0.330 & 0.303 & -1.090 \\
\hline Age & & & & & & & 0.013 & 0.005 & $2.576^{* *}$ \\
\hline Religiosity & & & & & & & 0.021 & 0.037 & 0.579 \\
\hline
\end{tabular}

$R^{2}=0.028$ for Step $1 ; \Delta R^{2}=0.004$ for Step $2 ;$ and $\Delta R^{2}=0.022$ for Step 3

$* p<0.10 ; * * p<0.05 ; * * * p<0.01$

Adjusted $R^{2}=0.038$

Perception of retributive justice was measured as defined in Table 3. Ninety percent level of confidence was used (Farrar et al., 2019; Steiger, 2004). Other variables are defined in Table 3 


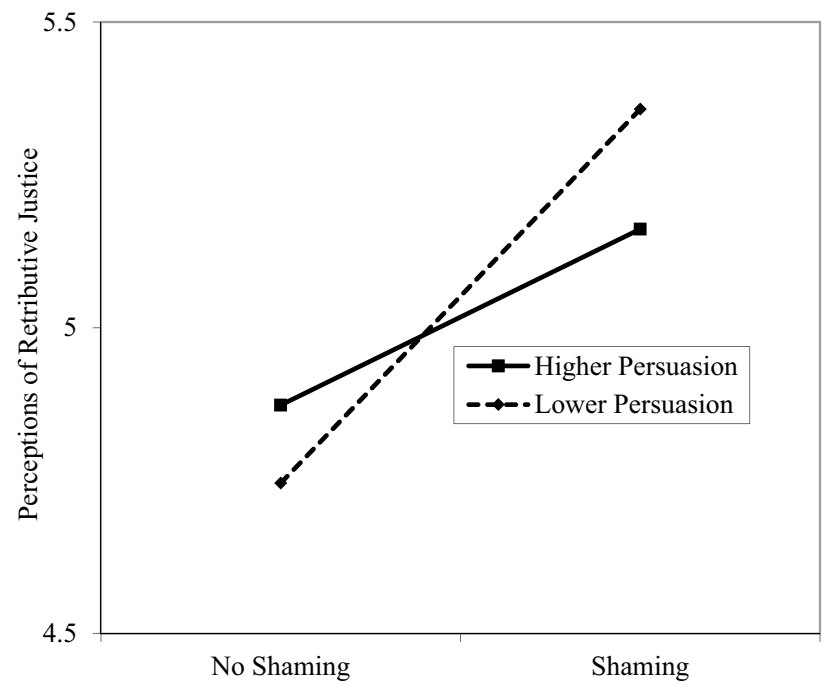

Fig. 3 The interactive effect of shaming and persuasion (higher vs lower) on perceptions on retributive justice. Shows perceptions of retributive justice relative to shaming tax evaders (shaming versus no shaming), salience of persuasion of observers (higher persuasion versus lower persuasion), and their two-way interaction based on hierarchical regression results from Experiment 1. The dependent variable is perceptions of retributive justice. All variables are defined in Table 3

coefficient of shaming is positive and significant at $p<0.01$ across three steps, which suggests that shaming of tax evaders increases observers' perceptions of retributive justice, with or without controls. Therefore, the results support Hypothesis 2. The coefficient of persuasion is positive but insignificant, which suggests that higher persuasion has a minimal effect on observers' perceptions of retributive justice. The coefficient of the two-way interaction between shaming and persuasion is also insignificant; therefore, the moderation effect is insignificant. Persuasion is not a statistically significant moderator of the linear relationship between shaming and perceptions of retributive justice. Figure 3 graphically presents these findings. Hypothesis $3 \mathrm{~b}$ is not supported. The results further show that perception of retributive justice is stronger among older observers because the coefficient of age is positive and significant $(p<0.05)$. Overall, shaming of tax evaders positively influences thirdparty observers' perceptions of retributive justice, but persuasion and the interaction of shaming and persuasion have no significant impact on perceptions of retributive justice in shaming punishments by third-party observers.

\section{Indirect Effect of Shaming on Tax Compliance Intentions}

Hayes PROCESS macro Model was used to examine the indirect effects of shaming on tax compliance intentions. Specifically, Model 4 was used to investigate whether
Table 7 Indirect effect of shaming on tax compliance intentions

\begin{tabular}{lllll}
\hline Mediator & Effect & BootSE & BootLLCI & BootULCI \\
\hline $\begin{array}{l}\text { Perceptions of retributive } \\
\text { justice }\end{array}$ & 0.355 & 0.138 & 0.140 & 0.592 \\
\hline
\end{tabular}

Adjusted $R^{2}=0.34$. Ninety percent level of confidence was used for the confidence intervals provided above (Farrar et al.,2019; Steiger, 2004). Hayes PROCESS Model 4 bootstrap analysis with 5000 resamples was used. The effect is significant, as all values in the confidence interval are positive. The direct effects of all predictor variables are consistent with the results in Step 3 of Table 5 and are therefore not tabulated. All variables are defined in Table 3

perceptions of retributive justice mediate the effect of shaming on tax compliance intentions. As in the hierarchical multiple regression analyses, persuasion, the interaction of shaming and persuasion, age and religiosity were included as covariates. The indirect effect of shaming on tax compliance intentions bootstrapped 5,000 times is significant (effect $=0.355$, CI 0.140 to 0.592 ), and its direct effect is insignificant. $^{3}$ The total effect is 0.643 , with a $t$ value of 2.874 , indicating a statistically significant effect $(p<0.01)$. The mediator, perceptions of retributive justice, accounted for approximately $55 \%$ of the total effect on tax compliance intentions. This finding supports Hypothesis 5. Table 7 shows the results of the indirect effect of shaming on tax compliance intentions. ${ }^{4}$

\section{Experiment 2}

\section{Preliminary Analyses}

Experiment 2 had two main objectives. First, it was designed to provide additional empirical evidence regarding the effects of shaming on perceptions of retributive justice and tax compliance intentions. Second, it used tax conviction notices to test Hypothesis $3 \mathrm{c}$ by exploring whether combining shaming with sanction appeals instead of normative appeals is more effective in persuading observers in the tax evasion setting. Recall that Experiment 1 included sanction appeals, normative appeals and incentives for compliance as higher persuasion and used normative appeals as lower persuasion. For Experiment 2, sanction and normative appeals were separated. The manipulation checks and outcomes for shaming and persuasion were successful for Experiment 2.

\footnotetext{
${ }^{3}$ Removing the interaction of shaming and persuasion as a covariate did not change the results.

${ }^{4}$ An additional analysis using Hayes PROCESS Model 8 (not tabulated or discussed) confirmed that persuasion does not moderate the mediated relationship between shaming and tax compliance intentions.
} 


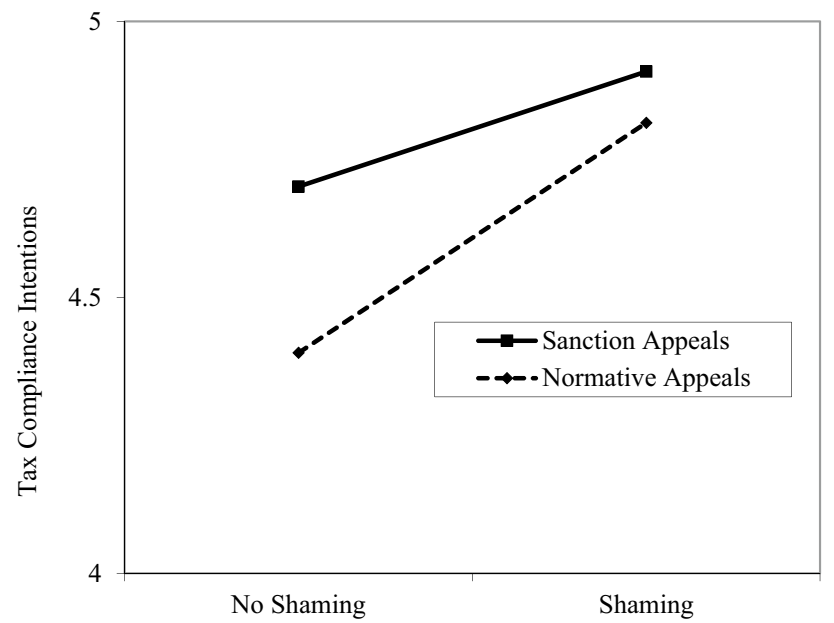

Fig. 4 The interactive effect of shaming and persuasion (sanction vs normative appeals) on tax compliance intentions. Shows tax compliance intentions relative to shaming tax evaders (shaming vs no shaming), salience of persuasion of observers (sanction appeals vs normative appeals), and their two-way interaction based on hierarchical regression results from Experiment 2. The dependent variable is tax compliance intentions. All variables are defined in Table 3

For example, participants gave higher scores to the question of whether the tax authority would be auditing more tax returns and prosecuting more tax evaders under the sanction appeals condition than under the normative appeals condition $(p<0.01)$.

\section{Hypothesis Tests}

Hierarchical regression analysis based on Experiment 2 provides supportive evidence for the effects of shaming. Experiment 2 also reinforces the strong link between perceptions of retributive justice and tax compliance intentions. Consistent with Experiment 1, shaming is positively related to perceptions of retributive justice and tax compliance intentions. However, compared to normative appeals, the main effect of sanction appeals is not significant in the shaming context and the interaction effect is not significant. Figure 4 graphically shows these results. Therefore, Hypothesis $3 \mathrm{c}$ is not supported. It is noteworthy that this result is not inconsistent with the result of Experiment 1 because persuasion was measured differently across the two experiments. The addition of control variables did not change the results. Interestingly, sanction appeals are noticeably more effective than normative appeals in the no-shaming context, consistent with the findings in Hasseldine et al. (2007).

\section{Discussion}

Tax authorities increasingly use non-pecuniary measures such as shaming and persuasion to improve taxpayers' perceptions of retributive justice and reduce noncompliance. This study used two experiments to investigate the effects of shaming punishments and persuasion on third-party observers' perceptions of retributive justice in shaming punishments and tax compliance intentions. Each experiment used a $2 \times 2$ between-subjects design. Shaming was operationalized as present or absent for both experiments, but the salience of persuasion was constructed differently for each experiment. Experiment 1 measured persuasion as higher (including sanction and normative appeals and incentives for compliance) or lower (containing only normative appeals), and Experiment 2 measured persuasion using sanction or normative appeals. Experiment 2 was performed to verify the consistency of the results found in Experiment 1 and investigate whether sanction appeals are more persuasive than normative appeals in a tax evasion setting involving shaming. Overall, this study provides consistent empirical evidence that shaming of tax evaders influences third-party observers' perceptions of retributive justice and tax compliance intentions. The results also demonstrate that perceptions of retributive justice mediate the relationship between shaming and tax compliance intentions. Moreover, this study finds that the effect of persuasion is context dependent and suggests caution in determining how third-party observers are persuaded when shaming tax evaders. For example, the main effect of higher persuasion on tax compliance intentions is positive and significant, but the effect of shaming tax evaders on third-party observers' tax compliance intentions is not stronger under higher persuasion than under lower persuasion. The current study further suggests that shaming is positively related to perceptions of retributive justice, while persuasion does not have any substantial impact on observers' perceptions of retributive justice, which is an intuitive finding.

This study provides several theoretical and practical contributions. First, although previous studies provide some evidence that shaming affects the payment of delinquent tax debts in the direction anticipated by policy makers, they call for more studies on the effects of shaming on other aspects of tax compliance, including tax evasion and tax avoidance (Perez-Truglia \& Troiano, 2018). The current study answers this call and extends the shaming literature to the tax evasion setting. The empirical results from two experiments based on different samples of Canadian taxpayers suggest that the publicizing of convictions and punishments of tax evaders by the tax authority significantly increases the 
compliance intentions of taxpayers who observe the shaming punishments.

Second, this study demonstrates that the content of messages conveyed in written communications of tax agency conviction notices also influences the tax compliance intentions of third-party observers. This study used the Yale Model of Persuasion and Hasseldine et al.'s (2007) persuasive communications to define higher persuasion as an integrated message consisting of sanction appeals, normative appeals and incentives for compliance. The findings suggest that the tax authority may use higher persuasion to increase tax compliance intentions as a substitute for shaming, with largely the same results. ${ }^{5}$ This study further suggests that when higher persuasion (an integrated message) is used, the tax agency's objective of curtailing tax evasion may materialize.

Third, this study presents evidence on the combined effects of shaming and persuasion on tax compliance intentions. The investigation of whether persuading taxpayers while shaming tax evaders jointly influences compliance intentions was largely motivated by insights from previous studies (Hasseldine et al., 2007; Hovland et al., 1953; PerezTruglia \& Troiano, 2018; Sherman, 1993) and observed inconsistencies in the reporting formats of conviction notices (Okafor \& Farrar, 2021). This study recommends that tax authorities that use shaming should ensure the absence of selection bias and apply shaming and its reporting format consistently to all taxpayers convicted of tax fraud. However, the results of this study suggest that combining shaming with higher persuasion may not be beneficial for the tax authority. In contrast, tax authorities may combine shaming with lower persuasion (normative appeals), or use only higher persuasion as previously noted.

Fourth, the current study also contributes to the retributive justice literature. The results suggest that shaming of evaders influences perceptions of retributive justice by thirdparty observers. This finding complements the extant tax literature on retributive justice (e.g., Kirchler et al., 2008; Okimoto \& Wenzel, 2009; Rechberger et al., 2010). Notably, the results suggest that persuasion does not have significant influence on observers' perceptions of retributive justice. One possible interpretation of this finding is that retributive justice judgment is the extent to which punishment is perceived as fair (van Prooijen \& Lam, 2007), and it does not depend on nuances of communication. The finding that perceptions of retributive justice mediate the relationship between shaming and tax compliance intentions further supports the notion that the perceived fairness of punishments of other taxpayers influences tax compliance intentions.

\footnotetext{
$\overline{5}$ The author thanks an anonymous reviewer for this suggestion.
}

Fifth, this study adds to the debate on the ethics of public shaming. Aitchison and Meckled-Garcia (2021) examine online public shaming as a form of punishment and mechanism for enforcing norms and suggest that it imposes reputational costs on the shamed subjects. They argue that online public shaming is an "ethically challenging product" of social media and digital technology and is morally wrong because it lacks due process and does not give fundamental respect to subjects as human beings. In discussing what justifies punishment and how offenders are punished, Markel (2001) also argues that shaming punishments are inconsistent with retribution. However, regarding whether nudges undermine human agency, Sunstein (2015) suggests that appropriate nudges promote human agency and consumer freedom. Sunstein (2017) challenges the notion that nudges are unethical as misconceived and argues that nudges always respect and promote human agency and can have considerable impacts. Reisch and Sunstein (2016) perform a survey of six European nations and find general broad public support for the use of nudges, particularly nudges that promote reflection and deliberation. They caution that people will reject nudges that are contrary to certain principles, such as "The government should not take people's money without their affirmative consent, even for a good cause" (p. 311). Therefore, their study generally suggests that the acceptability of nudges to the general public depends on context. The current study finds that participants consider shaming punishment for tax evasion as appropriate retribution against people who evade taxes. However, a conclusion on the morality of shaming could not be reached in this study because it did not investigate whether observers consider shaming to be morally acceptable. This study highlights the morality of shaming as is an important topic for future research. In summary, third-party observers perceive shaming of tax evaders as an appropriate form of retributive justice, their intended tax compliance increases with shaming, and their perceived retributive justice is strongly associated with their tax compliance intentions. These findings underscore the need for authorities to be firm but fair in upholding tax law and providing justice. Importantly, these findings are relevant to tax authorities concerned about the morality of shaming or that believe substantial tax revenue will be lost without engaging in shaming. The results suggest that higher persuasion is a viable alternative with minimal cost.

Taken together, the results of this study provide strong empirical evidence that shaming and persuasion have positive impacts on observers' tax compliance intentions. Although this study focused on tax compliance intentions and not actual behaviors, previous studies suggest that the intentions of individuals strongly predict their actual behaviors (Alm et al., 2015; Carpenter \& Reimers, 2005; Farrar et al., 2019; Fishbein \& Ajzen, 1975). Beliefs and attitudes are associated with intentions, which are linked to actual 
behaviors (Fishbein \& Ajzen, 1975). Therefore, to the extent that intentions predict actual behaviors, the empirical evidence from the current study suggests that tax authorities may effectively use shaming and persuasion to reduce noncompliance. Specifically, this study suggests that shaming of evaders may have a general deterrence effect. From a general deterrence perspective, this study reveals that shaming tax evaders is in the interest of the public because it communicates to third-party observers that evaders received the punishment that they deserved, and shaming of evaders influences observers' compliance intentions. This study provides additional evidence that the treatment of others affects thirdparty observers. The analysis of persuasion effects presented an opportunity to examine the efficacy of using sanction appeals versus normative appeals on tax compliance intentions. The findings suggest that in a no-shaming context, the effect of sanction appeals on the tax compliance intentions of third-party observers is substantially higher than that of normative appeals, and this evidence supports Hasseldine et al. (2007). In conclusion, this study proposes that shaming and higher persuasion are effective and substitutionary as enforcement mechanisms for tax authorities. However, the ethicality of shaming is not settled and is recommended for future study.

This study has some limitations. First, laboratory experiments may have low ecological and external validity. Unlike field experiments, laboratory experiments generally have an artificial setting that may produce a behavior that does not reflect a real-life situation. ${ }^{6}$ However, researchers suggest that more laboratory experiments should be performed in the social sciences because all experiments (laboratory, laboratory-like and field) are major sources of knowledge that complement each other, and the results of all experimental methods are generalizable (Charness et al., 2013; Falk \& Heckman, 2009; Viceisza, 2016). Previous studies also suggest that laboratory tax compliance experiments have external validity (e.g., Alm et al., 2015). Effectively, this concern is partially ameliorated.

Second, the effect sizes of shaming and persuasion were small, which may be interpreted as low practical relevance. However, this study suggests that the use of shaming and persuasion is justified, even with small effects, because the tax authority expends fewer resources to implement these efforts compared to audits. This statement is consistent with the suggestions in Bardach (1989) and Hasseldine et al. (2007), that the use of persuasive communications as a tax enforcement strategy is justified even if they only lead to small increases in compliance because they are relatively inexpensive to implement.

\footnotetext{
6 The author thanks an anonymous reviewer for this comment.
}

Third, the two experiments were performed using Canadian taxpayers. While this construction and consistent results are valuable to Canadian tax authorities, the findings may not be generalizable to countries where the government and legal system have low legitimacy. The strong association of shaming with the perceptions of retributive justice and tax compliance intentions may reflect the level of trust in the country's tax authority and justice system. For example, Canadian taxpayers may see the publicizing of convictions as the CRA legitimately enforcing just laws. Therefore, it would be interesting to see whether this association is found in countries where taxpayers do not trust their government or legal system, which would suggest that shaming may not be as effective in that location. ${ }^{7}$ A cross-country study should be performed to explore whether trust in the country's government and justice system influences the effects of shaming and persuasion on perceptions of retributive justice and tax compliance intentions.

Finally, some respondents' answers may be biased. However, measures were taken to mitigate social desirability bias. For example, the participants were guaranteed anonymity (Otaye-Ebede et al., 2020), and third-person measures were used to design the scales for perceptions of retributive justice in the punishment of tax evaders and tax compliance intentions because first-person measures of unethical or illegal behavior may lead to social desirability bias (Mascagni, 2018). A related caveat is that there may be a problem of endogeneity due to the design of the nudges. For example, some scenarios provided brief information versus substantial information. Likewise, some scenarios provided details of offences and punishments, while others provided general information. In addition, the inclusion of voluntary disclosure programs in the sanction appeals notice may have dampened the sanction. ${ }^{8}$ However, the manipulation checks for shaming and persuasion were successful, and actual conviction notices from the tax authority were adapted. Future research may further refine these measures. This study recommends that researchers build relationships with their tax authorities and acquire and use actual data to further investigate the effect of shaming and persuasion in the tax evasion setting.

Supplementary Information The online version contains supplementary material available at https://doi.org/10.1007/s10551-021-05011-y.

Acknowledgements The author thanks Dr. Jonathan Farrar of Wilfrid Laurier University and Dr. Amy Hageman of Kansas State University for their valuable suggestions. The author also thanks Professor Steven Dellaportas (section editor) and two excellent anonymous reviewers

\footnotetext{
7 The author thanks an anonymous reviewer for raising this point.

8 The author thanks an anonymous reviewer for this comment.
} 
for their helpful comments and suggestions on prior versions of this manuscript.

Author Contributions ONO designed the study, performed the experiments, analyzed the data, and wrote the manuscript.

Funding The author gratefully acknowledges financial support from the Social Sciences and Humanities Research Council (SSHRC) of Canada (Number: 136098), the CPA Canada and the Canadian Academic Accounting Association.

Data Availability Data that support the findings of this study are available as supplementary materials.

Code Availability Not applicable.

\section{Declarations}

Conflict of interest Oliver Nnamdi Okafor declares that he has no conflicts of interest.

Open Access This article is licensed under a Creative Commons Attribution 4.0 International License, which permits use, sharing, adaptation, distribution and reproduction in any medium or format, as long as you give appropriate credit to the original author(s) and the source, provide a link to the Creative Commons licence, and indicate if changes were made. The images or other third party material in this article are included in the article's Creative Commons licence, unless indicated otherwise in a credit line to the material. If material is not included in the article's Creative Commons licence and your intended use is not permitted by statutory regulation or exceeds the permitted use, you will need to obtain permission directly from the copyright holder. To view a copy of this licence, visit http://creativecommons.org/licenses/by/4.0/.

\section{References}

Abu-Bader, S., \& Jones, T. V. (2021). Statistical mediation analysis using the Sobel test and Hayes SPSS process macro. International Journal of Quantitative and Qualitative Research Methods. SSRN Retrieved from https://ssrn.com/abstract=3799204

Aiello, R. (2018). CRA does not consistently apply auditing rules to all taxpayers: AG. Retrieved November 6, 2020, from https:// www.ctvnews.ca/politics/cra-does-not-consistently-apply-audit ing-rules-to-all-taxpayers-ag-1.4184565

Aiken, L. S., West, S. G., \& Pitts, S. C. (2003). Multiple linear regression. Handbook of psychology (pp. 481-507). Wiley.

Aitchison, G., \& Meckled-Garcia, S. (2021). Against online public shaming: Ethical problems with mass social media. Social Theory and Practice, 47(1), 1-31.

Ali, M., Fjeldstad, O., \& Sjursen, I. H. (2014). To pay or not to pay? Citizens' attitudes toward taxation in Kenya, Tanzania, Uganda, and South Africa. World Development, 64, 828-842. https://doi. org/10.1016/j.worlddev.2014.07.006

Alm, J., \& Torgler, B. (2011). Do ethics matter? Tax compliance and morality. Journal of Business Ethics, 101(4), 635-651.

Alm, J., Blaufus, K., Fochmann, M., Kirchler, E., Mohr, P., Olson, N. E., \& Torgler, B. (2020). Tax policy measures to combat the SARS-CoV-2 pandemic and considerations to improve tax compliance: A behavioral perspective. WU International Taxation Research Paper Series, (2020-10). Retrieved September 2, 2021, from https://papers.ssrn.com/sol3/papers.cfm?abstract_ id $=3692370$
Alm, J., Bloomquist, K. M., \& McKee, M. (2015). On the external validity of laboratory tax compliance experiments. Economic Inquiry, 53(2), 1170-1186.

Bardach, E. (1989). Moral suasion and taxpayer compliance. Law \& Policy, 11(1), 49-69.

Baron, R. M., \& Kenny, D. A. (1986). The moderator-mediator variable distinction in social psychological research: Conceptual, strategic, and statistical considerations. Journal of Personality and Social Psychology, 51(6), 1173.

Beccaria, C. (2009). On crimes and punishments. ProQuest Ebook Central.

Benartzi, S., Beshears, J., Milkman, K. L., Sunstein, C. R., Thaler, R. H., Shankar, M., Tucker-Ray, W., Congdon, W. J., \& Galing, S. (2017). Should governments invest more in nudging? Psychological Science, 28(8), 1041-1055.

Bergman, M. S. (2003). Tax reforms and tax compliance: The divergent paths of Chile and Argentina. Journal of Latin American Studies, 35(3), 593-624.

Biesanz, J. C., Falk, C. F., \& Savalei, V. (2010). Assessing mediational models: Testing and interval estimation for indirect effects. Multivariate Behavioral Research, 45(4), 661-701.

Blank, J. (2009). What's wrong with shaming corporate tax abuse. Tax Law Review, 62(4), 539-590.

Blumenthal, M., Christian, C., Slemrod, J., \& Smith, M. G. (2001). Do normative appeals affect tax compliance? Evidence from a controlled experiment in Minnesota. National Tax Journal, 54(1), 125-138.

Bobek, D. D., Hageman, A. M., \& Kelliher, C. F. (2013). Analyzing the role of social norms in tax compliance behavior. Journal of Business Ethics, 115(3), 451-468.

Boone, J. P., Khurana, I. K., \& Raman, K. K. (2013). Religiosity and tax avoidance. Journal of the American Taxation Association, $35(1), 53-84$.

Bradley, G. V. (2003). Retribution: The central aim of punishment. Harvard Journal of Law \& Public Policy, 27, 19-32.

Braithwaite, J. (1989). Crime, shame and reintegration. Cambridge University Press.

Braithwaite, V., Murphy, K., \& Reinhart, M. (2007). Taxation threat, motivational postures, and responsive regulation. Law \& Policy, $29(1), 137-158$.

Bramall, R. (2018). A 'powerful weapon'? Tax, avoidance, and the politics of celebrity shaming. Celebrity Studies, 9(1), 34-52.

Branham, E. (2008). Closing the tax gap: Encouraging voluntary compliance through mass-media publication of high-profile tax issues. The Hastings Law Journal, 60(6), 1507-1533.

Cameron, K. A. (2009). A practitioner's guide to persuasion: An overview of 15 selected persuasion theories, models and frameworks. Patient Education and Counseling, 74(3), 309-317.

Canada Revenue Agency. (2020). Enforcement notifications: Compliance actions. Canada Revenue Agency. Retrieved October 21, 2020, from https://www.canada.ca/en/revenue-agency/news/ newsroom/criminal-investigations-actions-charges-convictions. html

Carpenter, T. D., \& Reimers, J. L. (2005). Unethical and fraudulent financial reporting: Applying the theory of planned behavior. Journal of Business Ethics, 60(2), 115-129.

Chang, L., \& Krosnick, J. (2010). Comparing oral interviewing with self-administered computerized questionnaires an experiment. Public Opinion Quarterly, 74, 154-167.

Charness, G., Gneezy, U., \& Kuhn, M. (2013). Experimental methods: Extra-laboratory experiments-extending the reach of experimental economics. Journal of Economic Behavior \& Organization, 91, 93-100.

Chung, J., \& Monroe, G. S. (2003). Exploring social desirability bias. Journal of Business Ethics, 44(4), 291-302. 
Cialdini, R. B., \& Trost, M. R. (1998). Social influence: Social norms, conformity and compliance. In D. T. Gilbert, S. T. Fiske, \& G. Lindzey (Eds.), The handbook of social psychology (pp. 151-192). McGraw-Hill.

Dawson, J. F. (2014). Moderation in management research: What, why, when, and how. Journal of Business and Psychology, 29(1), 1-19.

Department of Justice Canada. (2020). Criminal Code (R.S.C., 1985, c. C-46). Retrieved October 25, 2020, from https://laws-lois.justice. gc.ca/eng/acts/C-46/section-718.html\#: :text=(a)\%20to\%20den ounce $\% 20$ unlawful $\% 20$ conduct,other $\% 20$ persons $\% 20$ from $\%$ 20committing $\% 20$ offences $\% 3 \mathrm{~B} \&$ text $=(\mathrm{f}) \% 20$ to $\% 20$ promote $\%$ 20a\%20sense,victims\%20or\%20to\%20the\%20community

Devos, K., \& Zackrisson, M. (2015). Tax compliance and the public disclosure of tax information: An Australia/Norway comparison. eJournal of Tax Research, 13(1), 108-129.

Dwenger, N., \& Treber, L. (2018). Shaming for tax enforcement: Evidence from a new policy, CEPR Discussion Paper 13194. CEPR.

Edwards, J. R., \& Lambert, L. S. (2007). Methods for integrating moderation and mediation: A general analytical framework using moderated path analysis. Psychological Methods, 12(1), 1-22.

Elster, J. (1989). Social norms and economic theory. Journal of Economic Perspectives, 3(4), 99-117.

Falk, A., \& Heckman, J. J. (2009). Lab experiments are a major source of knowledge in the social sciences. Science, 326(5952), 535-538.

Farrar, J., Kaplan, S. E., \& Thorne, L. (2019). The effect of interactional fairness and detection on taxpayers' compliance intentions. Journal of Business Ethics, 154(1), 167-180.

Farrar, J., Massey, D. W., Osecki, E., \& Thorne, L. (2020). Tax fairness: Conceptual foundations and empirical measurement. Journal of Business Ethics, 162(3), 487-503.

Fishbein, M., \& Ajzen, I. (1975). Belief, attitude, intention, and behavior: An introduction to theory and research. Addison-Wesley.

Fisher, R. J. (1993). Social desirability bias and the validity of indirect questioning. Journal of Consumer Research, 20(2), 303-315.

Frey, B. S., \& Torgler, B. (2007). Tax morale and conditional cooperation. Journal of Comparative Economics, 35(1), 136-159.

Gangl, K., Muehlbacher, S., Groot, M., Hofmann, E., Kogler, C., \& Antonides, G. (2013). "How can i help you?" Perceived service orientation of tax authorities and tax compliance. FinanzArchiv Public Finance Analysis, 69(4), 487-510.

Garz, M., \& Pagels, V. (2018). Cautionary tales: Celebrities, the news media, and participation in tax amnesties. Journal of Economic Behavior \& Organization, 155, 288-300.

Government of Canada. (2018). Office of the Auditor General of Canada. 2018 fall reports of the Auditor General of Canada to the Parliament of Canada, report 7-compliance activities-Canada Revenue Agency. Retrieved December 8, 2020, from https://www. oag-bvg.gc.ca/internet/English/parl_oag_201811_07_e_43205. html

Hasseldine, J., Hite, P., James, S., \& Toumi, M. (2007). Persuasive communications: Tax compliance enforcement strategies for sole proprietors. Contemporary Accounting Research, 24(1), 171-194.

Hayes, A. F. (2018). Introduction to mediation, moderation, and conditional process analysis: A regression-based approach. Guilford Press.

Hovland, C. I., Janis, I. L., \& Kelley, H. H. (1953). Communication and persuasion: Psychological studies of opinion change. Yale University Press.

Hwang, S., \& Nagac, K. (2021). Religiosity and tax compliance: Evidence from U.S. counties. Applied Economics. https://doi.org/10. 1080/00036846.2021.1923638

Jasso, G., Törnblom, K. Y., \& Sabbagh, C. (2016). Distributive justice. In C. Sabbagh \& M. Schmitt (Eds.), Handbook of social justice theory and research (pp. 201-218). Springer.

Jimenez, P., \& Iyer, G. S. (2016). Tax compliance in a social setting: The influence of social norms, trust in government, and perceived fairness on taxpayer compliance. Advances in Accounting, 34, $17-26$.

Kaplan, S. E., Newberry, K. J., \& Reckers, P. M. (1997). The effect of moral reasoning and educational communications on tax evasion intentions. Journal of the American Taxation Association, 19(2), $38-54$.

Kim, C. K. (2002). Does fairness matter in tax reporting behavior? Journal of Economic Psychology, 23(6), 771-785.

Kim, T. Y., Cable, D. M., \& Kim, S. P. (2005). Socialization tactics, employee proactivity, and person-organization fit. Journal of Applied Psychology, 90(2), 232-241.

King, M. F., \& Bruner, G. C. (2000). Social desirability bias: A neglected aspect of validity testing. Psychology \& Marketing, 17(2), 79-103.

Kirchler, E., Hoelzl, E., \& Wahl, I. (2008). Enforced versus voluntary tax compliance: The "slippery slope" framework. Journal of Economic Psychology, 29(2), 210-225.

Latan, H., Jabbour, C., \& Jabbour, A. B. (2021). To blow or not to blow the whistle: The role of rationalization in the perceived seriousness of threats and wrongdoing. Journal of Business Ethics, 169(3), 517-535.

Lipatov, V. (2012). Corporate tax evasion: The case for specialists. Journal of Economic Behavior \& Organization, 81(1), 185-206.

Luttmer, E. F. P., \& Singhal, M. (2014). Tax morale. Journal of Economic Perspectives, 28(4), 149-168.

MacKinnon, D. P., Coxe, S., \& Baraldi, A. N. (2012). Guidelines for the investigation of mediating variables in business research. Journal of Business and Psychology, 27(1), 1-14.

MacKinnon, D. P., Fairchild, A. J., \& Fritz, M. S. (2007). Mediation analysis. Annual Review of Psychology, 58, 593-614.

Markel, D. (2001). Are shaming punishments beautifully retributive: Retributivism and the implications for the alternative sanctions debate. Vanderbilt Law Review, 54(6), 2157-2242.

Mascagni, G. (2018). From the lab to the field: A review of tax experiments. Journal of Economic Surveys, 32(2), 273-301.

Meade, A., \& Craig, B. (2012). Identifying careless responses in survey data. Psychological Methods, 17, 437-455.

Muller, D., Judd, C. M., \& Yzerbyt, V. Y. (2005). When moderation is mediated and mediation is moderated. Journal of Personality and Social Psychology, 89(6), 852-863.

Murphy, K. (2009). Procedural justice and affect intensity: Understanding reactions to regulatory authorities. Social Justice Research, $22(1), 1-30$.

OECD. (2019). Tax administration 2019: Comparative information on OECD and other advanced and emerging economies. OECD Publishing.

Okafor, O. N., \& Farrar, J. (2021). Punishing in the public interest: Exploratory Canadian evidence pertaining to convictions and incarcerations for tax offences. Journal of Accounting and Public Policy, 2021, 106848. https://doi.org/10.1016/j.jaccpubpol. 2021.106848

Okimoto, T. G., \& Wenzel, M. (2009). Punishment as restoration of group and offender values following a transgression: Value consensus through symbolic labelling and offender reform. European Journal of Social Psychology, 39(3), 346-367.

Otaye-Ebede, L., Shaffakat, S., \& Foster, S. (2020). A multilevel model examining the relationships between workplace spirituality, ethical climate and outcomes: A social cognitive theory perspective. Journal of Business Ethics, 166(3), 611-626.

Palazzo, G., Krings, F., \& Hoffrage, U. (2012). Ethical blindness. Journal of Business Ethics, 109(3), 323-338.

Pelletier, L. G., \& Sharp, E. (2008). Persuasive communication and proenvironmental behaviours: How message tailoring and message framing can improve the integration of behaviours through self-determined motivation. Canadian Psychology, 49(3), 210-217. 
Perez-Truglia, R., \& Troiano, U. (2018). Shaming tax delinquents. Journal of Public Economics, 167, 120-137.

Pierce, J. L., Gardner, D. G., Dunham, R. B., \& Cummings, L. L. (1993). Moderation by organization-based self-esteem of role condition-employee response relationships. Academy of Management Journal, 36(2), 271-288.

Radmacher, S. A., \& Martin, D. J. (2001). Identifying significant predictors of student evaluations of faculty through hierarchical regression analysis. The Journal of Psychology, 135(3), 259-268.

Rechberger, S., Hartner, M., Kirchler, E., \& Hämmerle, F. K. (2010). Tax amnesties, justice perceptions, and filing behavior: A simulation study. Law \& Policy, 32(2), 214-225.

Reisch, L., \& Sunstein, C. (2016). Do Europeans like nudges? Judgment and Decision Making, 11, 310-325.

Revenue Commissioners. (2020). Revenue publishes list of defaulters. Retrieved October 21, 2020, from https://www.revenue.ie/ en/corporate/press-office/press-releases/2020/pr-030320-reven ue-publishes-list-of-tax-defaulters.aspx

Rohrer, J. M. (2018). Thinking clearly about correlations and causation: Graphical causal models for observational data. Advances in Methods and Practices in Psychological Science, 1(1), 27-42.

Scheff, T. J., \& Retzinger, S. M. (1991). Lexington Books series on social theory. Emotions and violence: Shame and rage in destructive conflicts. Lexington Books/D.C. Heath and Company.

Sherman, L. W. (1993). Defiance, deterrence, and irrelevance: A theory of the criminal sanction. Journal of Research in Crime and Delinquency, 30(4), 445-473.

Shrout, P. E., \& Bolger, N. (2002). Mediation in experimental and nonexperimental studies: New procedures and recommendations. Psychological Methods, 7(4), 422-445.

Skarlicki, D. P., Ellard, J. H., \& Kelln, B. R. C. (1998). Third-party perceptions of a layoff: Procedural, derogation, and retributive aspects of justice. Journal of Applied Psychology, 83(1), 119-127.

Slemrod, J. (2019). Tax compliance and enforcement. Journal of Economic Literature, 57(4), 904-954.

Steiger, J. H. (2004). Beyond the F test: Effect size confidence intervals and tests of close fit in the analysis of variance and contrast analysis. Psychological Methods, 9(2), 164-182.

Stone-Romero, E. F., \& Rosopa, P. J. (2004). Inference problems with hierarchical multiple regression-based tests of mediating effects. Research in Personnel and Human Resources Management, 23, 249-290.
Sunstein, C. R. (2015). Nudges do not undermine human agency. Journal of Consumer Policy, 38(3), 207-210.

Sunstein, C. R. (2017). Misconceptions about nudges. SSRN Electronic Journal. https://doi.org/10.2139/ssrn.3033101

Taing, H. B., \& Chang, Y. (2021). Determinants of tax compliance intention: Focus on the theory of planned behavior. International Journal of Public Administration, 44(1), 62-73.

Tyler, T. R. (1990). Why people obey the law. Yale University Press. Retrieved December 25, 2020, from http://www.des.ucdavis.edu/ Faculty/Sabatier/Tyler1990.pdf

Vainre, M., Aaben, L., Paulus, A., Koppel, H., Tammsaar, H., Telve, K., Koppel, K., Beilmann, K., \& Uusberg, A. (2020). Nudging towards tax compliance: A fieldwork-informed randomised controlled trial. Journal of Behavioral Public Administration. https:// doi.org/10.30636/jbpa.30631.30684

van Prooijen, J.-W., \& Lam, J. (2007). Retributive justice and social categorizations: The perceived fairness of punishment depends on intergroup status. European Journal of Social Psychology, 37(6), 1244-1255.

Vermunt, R., \& Steensma, H. (2016). Procedural justice. In C. Sabbagh \& M. Schmitt (Eds.), Handbook of social justice theory and research (pp. 237-256). Springer.

Viceisza, A. C. G. (2016). Creating a lab in the field: Economics experiments for policymaking. Journal of Economic Surveys, 30(5), $835-854$.

Violette, G. R. (1989). Effects of communicating sanctions on taxpayer compliance. Journal of the American Taxation Association, 11(1), 92-104.

Wenzel, M. (2002). The impact of outcome orientation and justice concerns on tax compliance: The role of taxpayers' identity. Journal of Applied Psychology, 87(4), 629-645.

Wenzel, M., \& Okimoto, T. G. (2016). Retributive justice. In C. Sabbagh \& M. Schmitt (Eds.), Handbook of social justice theory and research (pp. 237-256). Springer.

Wenzel, M., \& Thielmann, I. (2006). Why we punish in the name of justice: Just desert versus value restoration and the role of social identity. Social Justice Research, 19(4), 450-470.

Wenzel, M., Okimoto, T., Feather, N., \& Platow, M. (2008). Retributive and restorative justice. Law and Human Behavior, 32(5), 375-389.

Publisher's Note Springer Nature remains neutral with regard to jurisdictional claims in published maps and institutional affiliations. 